South African Journal of Animal Science 2019, 49 (No. 6)

\title{
Effects of Lavender (Lavandula angustifolia) augmentation of alfalfa silages
}

\author{
A.A. Duru \\ Department of Animal Science, Faculty of Agriculture and Natural Sciences, Uşak University, Uşak, Turkey
}

(Received 13 November 2018; Accepted 17 December 2019; First published online 1 January 2020)

Copyright resides with the authors in terms of the Creative Commons Attribution 4.0 South African Licence.
See: http://creativecommons.org/licenses/by/4.0/za
Condition of use: The user may copy, distribute, transmit and adapt the work, but must recognise the authors and the South African
Journal of Animal Science.

\begin{abstract}
The aim of this study was to determine the chemical, fermentation, and microbiological properties of alfalfa silages that were augmented with lavender (Lavandula angustifolia) and to appraise their in vitro organic matter digestibility (IVOMD), metabolizable energy (ME), and net energy for lactation (NEL) contents. Lavender flowers were added to alfalfa silages at $0.5,1.0,1.5$, and $2.0 \%$ of the weight of alfalfa. An unaugmented alfalfa silage was also evaluated. After 75 day of ensiling, $\mathrm{pH}$, dry matter, NDF and ADF contents of alfalfa silages had decreased and OMD had increased with the addition of lavender. No significant differences in crude protein, ash, ether extract, lactic acid, acetic acid, propionic acid, lactic acid bacteria number, ME and NEL contents were detected. No butyric acid, Enterobacteriaceae, Listeria spp, sulphide reducing anaerobes, and yeasts were found in the alfalfa silages. Mould content decreased with the addition of lavender. Thus, the addition of lavender flowers to alfalfa silages may improve their quality.
\end{abstract}

Keywords: essential oil, fermentation, nutritional value, supplement

"Corresponding author: duru.asuman@gmail.com

\section{Introduction}

Lavender is an important medicinal plant grown in the Mediterranean region and an essential oil is obtained from its flowers (Guenther, 1952; Parejo et al., 2002; Popescu et al., 2015). Lavender, is tolerant of variation in soil types and grows best in calcareous soils. It is resistant to drought, heat and cold. Lavender can be propogated either vegitatively or from seed. The yield varies between 100 and $500 \mathrm{~kg}$ per acre depending on species, variety, climate and soil conditions (Aslancan \& Sarıbaş, 2011).

Feed costs account for 65-70 \% of total costs in ruminant livestock production. Alternative feed additives may reduce these costs and therefore improve economic production efficiency. Use of antibiotics used to in feeding animals that produce products for human consumption is prohibited in many countries due to concern over antibiotic resistance that could ultimately have negative affects on human health. A potential alternative to antibiotic use in animal feeding is the use of essential oils (Yadeghari et al., 2013). Essential oils obtained from lavender reportedly reduce production of methane gas in the rumen (Djabri et al., 2016). Thus, the aim of this study was to evaluate the use of lavender flower for feeding ruminant livestock through its incorporation into the ration by augmenting alfalfa silage.

\section{Materials and Methods}

Alfalfa was obtained from the growers operating in the region. Lavender was obtained from the Department of Crops Science of the Faculty of Agriculture and Natural Sciences of Uşak University. Lavender flowers were thoroughly mixed with alfalfa at $0.5,1.0,1.5$, and $2.0 \%$ of the total mass and an unaugmented alfalfa silage was also evaluated. The fresh material were ensiled 1 It plastic anaerob jars were kept at room temperature for 75 days. There were four replicates of each of the treatments. Essential oil components of the lavender were: $41.6 \%$ Linalol, 12.6\% 3-Cyclohexen-1-ol Terpinene44-ol, 10.5\% Borneol, 10.0\% Camphor, 2.3\% Beta-Pinene, 2.2\% 1-8 Cineole, 2.2\% Lavandulol, 1.6\% Malonic acid methyl ester 3,7 dimethyl 1-6 octadien 3 yl ester, and 1.4\% Beta Farnecene.

After 75 days of ensiling, the jars were opened, and the contents were sampled. Determination of dry matter (DM), ash, fat and crude protein followed AOAC (1990) protocols. Briefly, the samples were weighed and then dried in an air-circulating oven at $65^{\circ} \mathrm{C}$ for 48 hours after which time the samples were weighed 
again to determine DM. The dried samples were ground to a diameter of $1 \mathrm{~mm}$ and ash content was determined by burning the finely ground sample in a furnace for $4-6$ hours at $550{ }^{\circ} \mathrm{C}$. Crude fat (CF) content was determined through ether extraction. Crude protein (CP) content was determined from nitrogen released by the Kjeldahl method multiplied by 6.25 . Results of these analyses were expressed as a percentage of dry matter. Neutral detergent fiber (NDF) and acid detergent fiber (ADF) contents of silage samples were determined using Fiber Analyzer (Ankom Technology Corp. Fairport, NY, USA) device following Van Soest et al. (1991). The $\mathrm{pH}$ was measured with a digital $\mathrm{pH}$ meter by thoroughly mixing $100 \mathrm{ml}$ of distilled water and a $25 \mathrm{~g}$ sample of the silage and recording the pH of the slurry (Polan et al., 1998). In the same way, $40 \mathrm{~g}$ of silage samples were mixed with $360 \mathrm{ml}$ of distilled water, the mixture shaken for a minimum of 5 minutes, after which time it was poured through Whatman no: 1 paper, and $100 \mathrm{ml}$ of the filtered solution was to determine ammoniacal nitrogen $\left(\mathrm{NH}_{3}-\mathrm{N}\right)$ using the Kjeldahl distillation method (Broderick and Kang, 1980). An additionnal $10 \mathrm{ml}$ of this filtered solution centrifuged for 30 minutes at 14,000 revolutions per minute and acetic acid (AA), propionic acid (PA) and butyric acid (BA) and lactic acid concentrations were determined using high performance liquid chromatography (Column: C18, $5 \mu \mathrm{m}, 4.6 \times 250-\mathrm{mm}$; Mobile Phase: Isocratic; 25-mM K-phosphate buffer; pH 2.4; Flow Rate: $1.5 \mathrm{~mL} / \mathrm{min}$.; Column Temperature: $30{ }^{\circ} \mathrm{C}$; UV Sensor: Wavelength: $210 \mathrm{~nm}$; Injection Volume: $20 \mu \mathrm{L}$ ).

Sulfide reducing anaerobes in the silages were determined according to the method of Stanley et al. (1971). The numbers of lactic acid bacteria, Enterobacteriaceae, Listeria spp., yeast and moulds were determined following Harrigan (1998).

To determine IVOMD and ME levels of silages, the in vitro gas production technique proposed by Menke and Steingass (1988) was used. Net energy for lactation was calculated using equations found in Blümmel and Ørskov (1993).

The data analyzed with SPSS verison 16.0 (SPSS, Inc. Chicago. Illinios, USA). The sigificance of treatment effects was determined by one-way analysis of varaince and mean speparation was done with Duncan's multiple range procedure. Analyses of the lactic acid bacteria and moulds were conducted with the Frequency procedure.

\section{Results and Discussion}

The effect of augmenting alfalfa silage with lavender on the proximate analysis of the silages is shown Table 1. The dry matter content of alfalfa silages was increased with the addition of lavender $(P<0.01)$. No significant differences in crude ash, crude protein and ether extract contents were detected among treatments $(P>0.05)$. Nadeau et al. (2000a) observed similar results for alfalfa silages treated with cellulase, inoculant, and formic acid. Similar results were also obtained for alfalfa silage augmented with pre-fermented juices of barley, wheat and grass (Denek et al., 2012). Similarly, relative to the control alfalf silage, the NDF and ADF contents of the silages decreased with the addition of lavender. However, the amount of lavender augmentation had no affect on either NDF or ADF content of the silages. The observed reductions in fibre levels in the augmented silages are also supported by numerous reoprts in the literature (Goering et al., 1991; Sheperd et al., 1995; Nadeau et al., 1996; Nadeau et al., 2000b; Kung et al., 2003; Ce et al., 2016).

Table 1 Nutrition composition of alflafa silages augemented with lavender

\begin{tabular}{ccccccc}
\hline Treatment & DM, \% & Ash, \% DM & NDF, \% DM & ADF, \% DM & CP, \% DM & EE, \% DM \\
\hline Control & $24.81 \pm 0.98^{\mathrm{c}}$ & $13.49 \pm 0.77$ & $37.13 \pm 1.56^{\mathrm{a}}$ & $28.47 \pm 0.66^{\mathrm{a}}$ & $18.83 \pm 0.91$ & $3.08 \pm 0.96$ \\
$0.5 \%$ & $26.20 \pm 0.24^{\mathrm{b}}$ & $13.80 \pm 0.84$ & $33.25 \pm 0.89^{\mathrm{b}}$ & $26.54 \pm 0.59^{\mathrm{b}}$ & $18.98 \pm 0.86$ & $2.90 \pm 0.59$ \\
$1.0 \%$ & $26.70 \pm 0.24^{\mathrm{ab}}$ & $13.98 \pm 0.31$ & $33.12 \pm 1.70^{\mathrm{b}}$ & $26.16 \pm 1.05^{\mathrm{b}}$ & $19.03 \pm 0.70$ & $3.03 \pm 0.71$ \\
$1.5 \%$ & $27.34 \pm 0.79^{\mathrm{a}}$ & $13.92 \pm 0.61$ & $33.38 \pm 1.20^{\mathrm{b}}$ & $26.13 \pm 1.22^{\mathrm{b}}$ & $18.77 \pm 0.52$ & $2.97 \pm 0.47$ \\
$2.0 \%$ & $27.45 \pm 0.63^{\mathrm{a}}$ & $13.86 \pm 0.28$ & $33.75 \pm 2.20^{\mathrm{b}}$ & $26.53 \pm 1.26^{\mathrm{b}}$ & $18.16 \pm 0.67$ & $3.07 \pm 0.22$
\end{tabular}

${ }^{a, b, c}$ Within a column, means sharing a common superescript are not different $(P<0.05)$

DM: Dry matter; NDF: Neutral detergent fibre; ADF: Acid detergent fibre; CP: Crude protein; EE: Ether extract

Lavender significantly $(P<0.01)$ reduced the $\mathrm{pH}$ values of alfalfa silages, especially when augmented with $1.5 \%$ and $2.0 \%$ lavender flowers (Table 2). However, no significant difference was detected in the content of lactic, acetic acid and propionic acid of silages as a result of addition of lavender to alfalfa silages $(P>0.05)$. The quantity of lactic acid bacteria in the alfalfa silages in this study was found to be less than 
reported by Filya et al. (2001), Ke et al. (2015), and Wen et al. (2017) but similar to the report of Canbolat et al. (2013). The reason for using essential oils to augment alfalfa is to prevent the development of harmful microorganisms in the silage and improve its fermentation characteristics. In the present study, the concentration (cfu/kg) of desirable lactic acid bacteria was increased by augmentation with lavender (control $=4.39 \pm 0.20$; augmented silages $=4.68 \pm 0.05$ ). The presence of Enterobacteriaceae, Listeria spp, sulphite reducing anarobes, and yeast were not detected and moulds were only found in a fraction of the samples. The lack of these undesirable microorganisms indicates proper fermentation with a rapid reduction in $\mathrm{pH}$ after ensiling. Tengerdy et al. (1991), Çiftçi et al. (2005), Zhang et al. (2009), and Canbolat et al. (2011) have reported similar results in alfalfa silages that were augmented with either lactic acid bacteria or additional carbohydrate-containing juices.

Table $2 \mathrm{pH}$ and organic acid contents of alfalfa silages augemented with lavendar flowers

\begin{tabular}{cccccc}
\hline Treatment & $\mathrm{pH}$ & Lactic acid, \% & Acetic acid, \% & Propyonic acid, \% & Butyric acid, \% \\
\hline Control & $5.09 \pm 0.04^{\mathrm{a}}$ & $2.50 \pm 0.07$ & $0.74 \pm 0.07$ & $0.16 \pm 0.01$ & 0.00 \\
$0.5 \%$ & $4.98 \pm 0.03^{\mathrm{bc}}$ & $2.09 \pm 1.56$ & $0.93 \pm 0.08$ & $0.23 \pm 0.05$ & 0.00 \\
$1.0 \%$ & $5.01 \pm 0.03^{\mathrm{b}}$ & $2.88 \pm 1.42$ & $0.80 \pm 0.06$ & $0.13 \pm 0.02$ & 0.00 \\
$1.5 \%$ & $4.92 \pm 0.06^{\mathrm{c}}$ & $2.26 \pm 0.50$ & $1.10 \pm 0.45$ & $0.16 \pm 0.07$ & 0.00 \\
$2.0 \%$ & $4.92 \pm 0.08^{\mathrm{c}}$ & $2.41 \pm 0.53$ & $0.66 \pm 0.17$ & $0.18 \pm 0.09$ & 0.00 \\
\hline
\end{tabular}

$\overline{a, b, c}$ Within a column, means sharing a common superescript are not different $(P<0.05)$

As a result of the addition of lavender to alfalfa silages, IVOMD increased significantly $(P<0.05$; Table 3). Non-significant numerical increases in ME and NEL were also observed $(P>0.05)$. The reduction of the plant cell wall components, resulting from the augmentation of the alfalfa with lavender and manifest as NDF and ADF may have been responsible for the increased IVOMD. These findings for IVOMD are similar to those reported by Contreras-Govea et al. (2011), Canbolat et al. (2013), and Koc et al. (2008) for augmented alfalfa silages.

Table 3 Nutritional value of alfalfa silages augmented with lavendar flowers as predicted from in vitro gas production

\begin{tabular}{cccc}
\hline Treatment & IVOMD, $\%$ & ME, MJ/kg DM & NEL, MJ/kg DM \\
\hline Control & $55.35 \pm 0.91^{\mathrm{b}}$ & $7.47 . \pm .1 .12$ & $4.44 \pm 0.82$ \\
$0.5 \%$ & $67.97 \pm 3.95^{\mathrm{a}}$ & $8.21 . \pm .0 .97$ & $4.97 \pm 0.72$ \\
$1.0 \%$ & $66.94 \pm 5.68^{\mathrm{a}}$ & $8.54 . \pm .0 .90$ & $5.24 \pm 0.73$ \\
$1.5 \%$ & $66.76 \pm 1.79^{\mathrm{a}}$ & $8.51 . \pm .0 .22$ & $5.21 \pm 0.14$ \\
$2.0 \%$ & $69.14 \pm 2.71^{\mathrm{a}}$ & $8.88 . \pm .0 .43$ & $5.50 \pm 0.34$
\end{tabular}

${ }^{a, b}$ Within a column, means sharing a common superescript are not different $(P<0.05)$
IVOMD: in vitro organic matter digestibility, ME: Metaboliable energy, NEL: Net energy for lactation

Alfalfa is a difficult crop to ensile because conditions required for the fermentation required to produce good quality silage may not be obtained (Bolsen et al., 1996). Improper fermentation can result in proliferation of undesirable microorganisms and loss of DM. What determines the quality of silages is $\mathrm{pH}$ and the amount of lactic acid formed during fermentation. Butyric acid bacteria are the most important competitor of acetic acid bacteria during the fermentation of silages. Formation of butyric acid in silage can result in a marked loss of nutrients. Therefore, butyric acid is not desired in silages. Hashemzadeh-Cigari et al. (2014) stated that lactic acid content did not change with the addition of additives to alfalfa silages. Tabacco et al. (2006) reported that no butyric acid content occurs as a result of adding additive to alfalfa silages. 


\section{Conclusion}

The addition of lavender flower at different levels to alfalfa silage improved its fermentation properties without decreasing its nutritional value. Thus, better silages were obtained and it may be concluded that lavender has potential to be used as a preservative in alfalfa silages.

\section{Conflict of Interest Declaration} results.

The author has no conflict of interest that would compromise the conduct of this work or interpretation of the

\section{References}

Ankom, 1998. Procedures for fibre and in vitro analysis. Asseda http://www.ankom.com

Aslancan, H. \& Sarıbaş, R. 2011. Lavanta Yetiştiriciliği. Meyvecilik Araştırma Enstitüsü Müdürlüğü. Yayın No. 41.

Association of Official Analytical Chemists (AOAC), 1990. Official Method of Analysis. 15th ed., pp. 66-88, Washington, DC, USA, 1990.

Blümmel, M. \& Ørskov, E.R., 1993. Comparison of in vitro gas production and nylon bag degradabilities of roughages in predicting food intake of cattle. Anim. Feed. Sci. Tech. 40, 109-119.

Bolsen, K.K., Ashbell, G. \& Weinberg, Z.G., 1996. Silage fermentation and silage additives. Asian Austral. J. Anim. Sci. 9(5), 483-493, 1996.

Broderick, G.A. \& Kang, J.H., 1980. Automated simultaneous determination of ammonia and total amino acids in ruminal fluid and in vitro media. J. Dairy Sci., 63, 64-75.

Canbolat, Ö., Kalkan, H. \& Filya, İ., 2013. Yonca Silajlarında Katkı Maddesi Olarak Gladiçya Meyvelerinin (Gleditsia Triacanthos) Kullanılma Olanakları. Kafkas Üniv. Vet. Fak. Derg. 19(2), 291-297. (In Turkish).

Canbolat, Ö., Kalkan, H., Karaman, Ş. \& Filya, İ., 2010. Üzüm Posasının Yonca Silajlarında Karbonhidrat Kaynağı Olarak Kullanılma Olanakları. Kafkas Univ. Vet. Fak. Derg. 16(2), 269-276. (İn Turkish).

Ce, L., Yu-jiao, L., Xiao-nan, L., Ping-ting, G. \& Hai-ling, L., 2016. Effect of lactic acid bacteria inoculants on alfalfa (Medicago sativa L.) silage quality: assessment of degradation (in situ) and gas production (in vitro). J. Integrative Agric. 15(12,: 2834-2841.

Contreras-Govea, F.E., Muck, R.E., Mertens, D.R. \& Weimer, P.J., 2011. Microbial inoculant effects on silage and in vitro ruminal fermentation, and microbial biomass estimation for alfalfa, bmr corn, and corn silages. Anim. Feed Sci. Tech. 163, 2-10.

Çiftçi M., Çerçi, H.İ., Dalkılıç, B., Güler, T. \& Ertaş, O.N., 2005. Elmanın karbonhidrat kaynağı olarak yonca silajına katılma olanağının araştırılması. YYÜ Vet. Fak. Derg. 16(2), 93-98. (In Turkish).

Denek, N., Can, A., Avcl, M. \& Aksu, T., 2012. The effect of fresh and frozen pre-fermented juice on the fermentation quality of alfalfa silage. Kafkas Unv. Vet. Fak. Derg,18(5), 785-790.

Djabri, B., Rouabhi, R., Arhab, R., Attar, F. \& Bousseboua, H. 2016. Antimethanogenic activity of essential oils extracted from Rosmarinus officinalis and Lavandula officinalis. Bioech. Indian J. 12(2), 107-112.

Filya İ., Ashbell G., Weinberg Z.G. \& Hen Y., 2001. Hücre duvarını parçalayıcı enzimlerin yonca silajlarının fermantasyon özellikleri, hücre duvarı kapsamı. ve aerobik stabiliteleri üzerine etkileri. Ankara Üniv. Zir. Fak. Tarım. Bilim. Derg. 7(3), 81-87. (In Turkish).

Goering, H.K., Waldo, D.R., Tyrrell, H.F. \& Thomson, D.J., 1991. Composition of formaldehyde- and formic acid-treated alfalfa and orchardgrass silages harvested at two maturities and their effects on intake and growth by Holstein heifers. J Anim Sci. 69(11), 4634-4643.

Guenther, E., 1952. The Essential Oils. D. Van Nostrand Co. New York, USA.

Harrigan, W. F., 1998. Laboratory methods in food microbiology 3rd ed., Academic Pres, London, UK.,

Hashemzadeh-Cigari, F., Khorvash, M., Ghorbani, G.R., Ghasemi, E., Taghizadeh, A., Kargar, S. \& Yang, W.Z., 2014. Interactive effects of molasses by homofermentative and heterofermentative inoculants on fermentation quality, nitrogen fractionation, nutritive value and aerobic stability of wilted alfalfa (Medicago sativa L) silage. J. Anim. Physiol. Anim. Nutr. 98, 290-299.

Ke, W.C., Yang, F.Y., Undersander, D.J. \& Guo, X.S., 2015. Fermentation characteristics, aerobic stability, proteolysis and lipid composition of alfalfa silage ensiled with apple or grape pomace Anim. Feed Sci. Tech. 202, 12-19.

Koc, F., Coskuntuna, L. \& Ozduven, L., 2008. The effect of bacteria+enzyme mixture silage inoculant on the fermentation characteristic, cell wall contents and aerobic stabilities of maize silage. Pak. J. Nutr. 7, 222-226.

Kung, L., Taylor, C.C., Lynch, M.P. \& Neylon, J.M., 2003. The effect of treating alfalfa with Lactobacillus buchneri 40788 on silage fermentation, aerobic stability, and nutritive value for lactating dairy cows. J. Dairy Sci. 86(1), 336-343.

Menke, K.H. \& Steingass, H., 1998. Estimation of the energetic feed value obtained from chemical analysis and in vitro gas production using rumen fluid. Anim. Res. Dev. 28, 7-55.

Nadeau, E.M.G, Russell, J.R. \& Buxton, D.R., 2000a. Intake, digestibility, and composition of orchardgrass and alfalfa silages treated with cellulase, inoculant, and formic acid fed to lambs. J. Anim. Sci. 78, 2980-2989.

Nadeau, E.M.G., Buxton, D.R., Lindgren, E. \& Lingvall, P., 1996. Kinetics of cell-wall digestion of orchardgrass and alfalfa silages treated with cellulase and formic acid. J. Dairy Sci. 79(12), 2207-2216.

Nadeau, E.M.G., Buxton, D.R., Russell, J.R., Allison, M.J. \& Young, J.W., 2000b. Enzyme, bacterial inoculant, and formic acid effects on silage composition of orchardgrass and alfalfa. J. Dairy Sci, 83, 1487-1502.

Parejo, I., Viladomat, F., Bastida, J., Rosas-Romero, A., Flerlage, N., S Burıllo, J. \& Codina, C., 2002. Comparison between the Radical Scavenging Activity and Antioxidant Activity of Six Distilled and Nondistilled Mediterranean Herbs and Aromatic Plants. J. Agric. Food Chem., 50, 6882-6890. 
Polan, C.E., Stive, D.E. \& Garrett, J.L., 1998. Protein preservation and ruminal degradation of ensiled forage treated with heat, formic acid, ammonia, or microbial inoculant, J. Dairy Sci. 81, 765-776.

Popescu, C., Pruteanu, A., Cujbescu, D., Grigore, I., Matache, M., Voicea, I., Vlăduț, V., Marin, E. \& Popescu, C., 2015. Physico-chemical and microbiological characterization of lavender water obtained as by-product from lavender (Lavandula angustifolia L.) essential oil. Proc. Internat. Symp. ISB-INMA TEH. Agric.Mech. Eng. Bucharest, Romania, 29-31 October 2015. Pp. 335-342.

Sheperd, A.C., Maslanka, M., Quinn, D. \& Kung, Jr., L., 1995. Additives containing bacteria and enzymes for alfalfa silage. J. Dairy Sci. 78, 565-572.

Stanley, E.R., Bradley, T.R. \& Sumner, M. A., 1971. Properties of the mouse embryo conditioned medium factor(s) stimulationg colony formation by mouse bone marrow cells grown in vitro. J. Cell. Physiol. 78, 301-317.

Tabacco, E., Borreani, G., Crovetto, G.M., Galassi, G., Colomne, D. \& Cavallarin L., 2006. Effect of chestnut tannin on fermentation quality, proteolysis, and protein rumen degradability of alfalfa silag. J. Dairy Sci., 89, 4736-4746.

Tengerdy, R. P., Weinberg, Z.G., Szakacs, G., Wu, M., Linden, J.C., Henk, L.L. \& Johnson, D.E., 1991. Ensiling alfalfa with additives of lactic acid bacteria and enzymes. J. Sci. Food Agric. 55:215-228.

Van Soest, P.J., Robertson, J.D., \& Lewis, B.A., 1991. Methods for dietary fibre, neutral detergent fibre and non-starch polysaccharides in relation to animal nutrition. J. Dairy Sci. 74, 3583-3597.

Yadeghari, S., Malecky, M., Zamani, P. \& Dehghan-Banadaky, M., 2013. In vitro evaluation of the effects of Lavandula officinalis and Origanum vulgare essential oils on ruminal fermentation using concentrate and roughage type substrates. J. Lvstk. Sci. Tech.1(2), 1-12.

Zhang T, Li L., Wang, X., Zeng, Z., Hu, Y. \& Cui,, Z., 2009. Effects of Lactobacillus buchneri and Lactobacillus plantarum on fermentation, aerobic stability, bacteria diversity and ruminal degradability of alfalfa silage. World J. Microbiol. Biotech. 25, 965-971. 